\title{
WYZWANIA W ZARZAZDZANIU ROZWOJEM MIASTA NA PRZYKŁADZIE DZIELNICY NOWA HUTA
}

\section{Abstract \\ Challenges in Management of Urban Development on the Example of Nowa Huta District}

The aim of this paper is to identify the challenges in management of urban development on the example of Nowa Huta. The work was divided into three parts, each of which discusses a different aspect concerning the essence of the subject. The first part refers to the history of Nowa Huta. Second part discusses problems in managing the development of the city. Last part refers to Nowa Huta and the challenges posed by the authorities in relation to its historical conditions, as well as the actions taken to date. To achieve the objective were used analysis of literature on the field of history, sociology, management development, social geography, strategic documents and materials available on the Websites. Analysis of literature allowed the development of applications which basis do further research in this area.

Key words: Cracow, Nowa Huta, management of urban development.

\section{Streszczenie}

Celem artykułu jest określenie wyzwań dla zarządzania rozwojem miasta na przykładzie dzielnicy Nowa Huta. Praca została podzielona na trzy części, z których każda omawia inny aspekt dotyczący istoty podejmowanego tematu. Pierwsza część odnosi się do historii Nowej Huty jako miasta socjalistycznego, kolejna omawia podstawowe problemy w zarządzaniu rozwojem miasta, ostatnia część odnosi się do Nowej Huty i wyzwań, jakie stawiają przez władzami jej historyczne uwarunkowania, a także dotychczas podjętych w tym obszarze działań. Dla osiągnięcia celu posłużono się analizą literatury z zakresu historii, socjologii, zarządzania rozwojem, geografii społecznej oraz dokumentów strategicznych i materiałów dostępnych na stronach internetowych zaangażowanych podmiotów. Analiza literatury pozwoliła na opracowanie wniosków będących podstawą do dalszych badań w tym obszarze.

Słowa kluczowe: Kraków, Nowa Huta, zarządzanie rozwojem miasta. 


\section{Wstęp}

Wzniesione przy kombinacie metalurgicznym idealne miasto socjalizmu, jakim w założeniu miała się stać Nowa Huta, przez dziesięciolecia umacniało swoją pozycję, tworzyło własną historię i budowało wspólnotę mieszkańców, często pochodzących z różnych zakątków kraju. Po okresie rozkwitu i stabilizacji Nowa Huta musiała zmierzyć się po 1989 roku z transformacją systemu oraz prywatyzacją majątku państwowego, która doprowadziła do upadku przemysłowego ośrodka, przekształcając go w miejsce dotknięte wysokim bezrobociem i problemami społecznymi. Mimo wielu przeszkód, Nowej Hucie po dwóch dekadach stagnacji udało się osiągnąć obecny status, dzielnicy odradzającej się, przed którą otwierają się nowe perspektywy. Nowa Huta z uwagi na wiele atutów zarówno przestrzennych, jak i społecznych jest miejscem o wysokim potencjale rozwoju. Jakie wyzwania stawia przed władzami miasta współczesna Nowa Huta? To pytanie zadaje sobie wielu badaczy, a także przedstawicieli władz lokalnych i mieszkańców.

\section{Nowa Huta w okresie socjalistycznym}

Rozważania o tym, czy w Polsce i innych krajach Europy Środkowej okres socjalizmu trwał na tyle długo, by zmienić zupełnie sieć osadniczą, trwają od lat, niemniej jednak przyjmuje się, iż w wielu ośrodkach miejskich socjalistyczne założenia wywarły istotny wpływ na kształtujące się więzi społeczne oraz tworzące się po transformacji obszary bezrobocia i stygmatyzacji. Władze socjalistyczne w pierwszej kolejności traktowały miasto jako narzędzie oddziaływania politycznego i ideowego, a dopiero później - jako centrum produkcji przemysłowej. $Z$ tego względu Nowa Huta jako miasto ideowo napiętnowane uległa stereotypizacji, stając się symbolem ograniczającego i sterującego człowiekiem systemu [Markowski, 1999].

Pierwszą koncepcję tak zwanego socgorodu jako formy miasta przemysłowego stworzył Mikołaj Aleksandrowicz Milutin. Forma ta zaczęła funkcjonować jako teoretyczna podstawa planowania przestrzennego miast przemysłowych Związku Radzieckiego i innych krajów socjalistycznych. Koncepcja miasta przemysłowego była zbieżna również z funkcjonującą koncepcją osiedla społecznego, którego zadaniem było wprowadzenie przeobrażeń społecznych oraz podniesienie warunków życia klasy robotniczej [Węcławowicz, 2007]. Idea, jaka przyświecała tworzeniu pierwszych osiedli „starej” Nowej Huty (rozumianej jako zespół zabudowy powstałej głównie w latach 1949-1955, usytuowanej wokół placu Centralnego, której granicą są ulice Bieńczycka i Kocmyrzowska na zachodzie, Bulwarowa i Klasztorna od strony wschodniej oraz Łąki Nowohuckie od południa), bazowała na projekcie jednostki sąsiedzkiej, zakładającej tworzenie osiedli dla kilkutysięcznej społeczności, integrującej się w umieszczonych centralnie ośrodkach integrujących, 
takich jak sklepy, przychodnie, szpitale oraz szkoły i przedszkola [Jeleński, 2010]. Założenia te wywarły mocny wpływ na kształtowanie się stosunków i więzi sąsiedzkich, opisywanych na początku lat 90. przez Allison Stenning, ujawniających się nie tyle we wzajemnej wymianie czasu i opieki, ile również w specyficznych uwarunkowaniach małych, nowohuckich przedsiębiorstw [Stenning, 2008].

Miasto socjalistyczne wywierało wpływ na strukturę ludności napływającej do nowo powstałych osiedli mieszkaniowych, bowiem obowiązek meldunku przynosił możliwość odsiewania „podejrzanych ideologicznie” mieszkańców. Społeczeństwo miasta socjalistycznego było więc kategorią w wielu przypadkach homogeniczną, w której przeważała klasa robotnicza. Zwyczaj lokalizowania osiedli przy dużych fabrykach tworzył dodatkowo osiedla jednozawodowe. Również pracownicy kombinatu byli początkowo przydzielani do tych samych osiedli względem wykonywanego zawodu lub jednostki zakładowej, w jakiej pracowali [Węcławowicz, 2007; Bujak, Ryłko, 2008]. Więź społeczna Nowej Huty wytworzyła się zatem nie poprzez tradycję czy wspólną historię, ale w sposób instytucjonalny, w którym rolę w tworzeniu się społeczności lokalnych odgrywał zakład pracy. Doprowadziło to do powstania etosu społeczności identyfikującej i opisującej siebie z perspektywy miejsca zajmowanego w określonej strukturze [Bujak, Ryłko, 2008]. W późniejszych latach skutkowało to trudnościami w odnalezieniu się w nowej rzeczywistości oraz miało ogromny wpływ na budowanie konkurencyjności Nowej Huty. Według Markowskiego [Markowski, 1999] etos społeczności jest bowiem wraz z lokalną kulturą, przedsiębiorczością, infrastrukturą i zagospodarowaniem głównym składnikiem systemu innowacji danego regionu. Nowohucki etos przyczynił się także do istniejącej do dziś izolacji względem starego Krakowa, przejawiającej się między innymi w językowych przyzwyczajeniach mieszkańców. Rytm dnia codziennego w Nowej Hucie w okresie socjalistycznym wyznaczał kombinat, natomiast zaplecze - w postaci sklepów, kawiarni, parków i skwerów - skutecznie ograniczało przemieszczanie się mieszkańców do „starego" centrum Krakowa (do dzisiaj w domach nowohucian podróż w stronę Rynku Głównego jest określana jako podróż „do Krakowa”). Do wzmacniania etosu przyczyniały się także prace i opinie badaczy Nowej Huty, które nie były wolne od ideologicznych przesłanek. Jako jeden z czynników usytuowania obiektu przemysłowego przy Krakowie wskazywano w nich chęć stworzenia silnego ośrodka, nowej socjalistycznej społeczności, która mogłaby wpłynąć ideologicznie na „zasiedziałą" ludność starego Krakowa oraz połączyć tradycję z pionierskimi formami nowego życia [Siemieńska, 1969].

Tożsamość Nowej Huty została wykreowana na podwalinach ideologii socjalistycznej i choć eksperyment w postaci miasta idealnego i człowieka socjalistycznego się nie powiódł - ze względu na wiele aspektów, zarówno religijnych, jak i kulturowych - to mieszkańcy Nowej Huty pozostali specyficzną grupą osób, często napiętnowaną przez panujące stereotypy swoją ,niehistorycznością" i robotniczym charakterem, pozostającą w cieniu uniwersyteckiego i kulturalnego centrum Krakowa. Trudności dzielnicy w okresie transformacji zostały uwarunkowane przede wszystkim przez historię opartą na założeniach socjalistycznych 
oraz dziesięciolecia odgórnie planowanego systemu pracy i życia przy zakładzie przemysłowym.

\section{Problemy w zarządzaniu rozwojem miasta}

Miasto traktowane jako organizacja podlega $\mathrm{w}$ zarządzaniu podobnym procesom i przemianom przypisywanym przedsiębiorstwom. Od menedżerów miast, czyli władz lokalnych, wymaga się jednak większej wiedzy i wrażliwości na przemiany społeczne, gospodarcze, przestrzenne i polityczne, a także umiejętności budowania strategii na dziesięciolecia. Rozwój miasta jest bowiem złożony z elementów i inwestycji, jakie mogą przynieść korzyści dopiero za kilkanaście lub kilkadziesiąt lat [Markowski, 1999]. Zarządzanie miastem jest więc efektywną formą rządzenia oraz kierowania rozwojem i wzrostem, wychodzącą naprzeciw stawianym wymaganiom, a także działalnością zapewniającą sprawne funkcjonowanie i rozwój ukształtowanej bazy osiedleńczej [Pęski, 1999].

Niewątpliwie najważniejszym elementem zarządzania miastem jest wieloetapowość podejmowanych działań oraz planowanie strategiczne, pozwalające przechodzić przez określone procesy przemian w sposób płynny, z odpowiednim wykorzystaniem dostępnych narzędzi i rozpoznaniem potencjału danego obszaru, a także wykorzystaniem dorobku z zakresu marketingu terytorialnego i przy należytym kreowaniu marki zarządzanego terytorium. Zarządzanie rozwojem miasta zależy od odpowiedniego przygotowania do podejmowania określonych decyzji, a także długookresowych kalkulacji kosztów i korzyści, jakie przynoszą nowe, wybrane ścieżki rozwoju [Markowski, 1999].

Najczęściej stosowanymi instrumentami prorozwojowymi w zarządzaniu miastem są specjalne strefy ekonomiczne, powstające często na wolnych przestrzeniach otaczających miasta i dzielnice. Tworzenie stref ma $\mathrm{z}$ reguły za zadanie przyciągnięcie kapitału zewnętrznego. W związku z tym zauważa się, że strefy ekonomiczne są miejscem generowania dochodów, a niekoniecznie zatrudnienia, zmieniając się w tak zwane enklawy rozwoju, niebiorące udziału w aktywizacji społeczności i wspieraniu przedsiębiorczości lokalnej. Jeżeli strefy nie są połączone z odpowiednim zapleczem szkoleniowym, doprowadzają do migracji osób $\mathrm{z}$ odpowiednim wykształceniem, zmieniając strukturę społeczną dzielnic oraz napędzając postępującą marginalizację i wykluczenie osób, które nie czerpią korzyści z inwestycji zewnętrznych ze względu na nieadekwatne do profilu nowych inwestorów kompetencje zawodowe [Markowski, 1999]. W opozycji do zarządzania rozwojem poprzez strefy ekonomiczne w literaturze zwraca się uwagę na zależność pomiędzy istnieniem dobrze rozwiniętej sieci małych i średnich przedsiębiorstw a korzystnymi tendencjami na rynku pracy. Małe przedsiębiorstwa są strefą buforową dla pracowników o różnym profilu zawodowym, w której następuje przekwalifikowanie zawodowe. Przedsiębiorstwa $\mathrm{z}$ tej grupy często inicjują wprowadzanie pewnych produktów na rynek, a także, jak pokazują przykłady, tworzą struktury elastyczne, idealnie dopasowane do konkurencyjnej gospodarki. 
Przedsiębiorstwa te, ze względu na często eksperymentalny charakter produkcji i działań, odznacza niski odsetek odnoszonych sukcesów i czas utrzymywania się na rynku, niemniej jednak są one źródłem pozytywnych efektów dla lokalnej gospodarki [Markowski, 1999]. Jednym z problemów, z jakimi muszą się zmierzyć władze lokalne, jest wspieranie przedsiębiorczości z uwzględnieniem specyfiki zarządzanego obszaru, odpowiednich zmian i polityki w tym zakresie.

Marginalizacja obszarów, czyli doprowadzenie do tego, że społeczność lokalna nie bierze udziału w dobrobycie, prowadzi do zwiększania kosztów społecznych, a działania zapobiegające wykluczeniu społecznemu wymagają wysokiego nakładu pracy i środków, choć wyniki działań są często widoczne dopiero w dłuższym okresie oddziaływania [Markowski, 1999]. Zmiany życia społecznego są pojęciem wymagającym spojrzenia z szerszej perspektywy, często nie tylko dotyczą indywidualnych upodobań, ale także są elementem procesów społecznych, w jakich uczestniczymy. Od społeczeństwa przemysłowego, poprzez ponowoczesne kształtuje się społeczeństwo globalne, analogicznie do tego procesu również od miasta socjalistycznego w procesie przemian tworzy się miasto ponowoczesne o zupełnie innym niż dotychczas kształcie [Karwińska, 2008]. Kluczem do sukcesu w nowoczesnych krajach, społeczeństwach i miastach, oprócz tradycyjnie pojmowanej infrastruktury, takiej jak drogi czy telekomunikacja, staje się infrastruktura intelektualna [Markowski, 1999]. Społeczeństwo ponowoczesne, jakie obecnie kształtuje się w Polsce, jest oparte przede wszystkim na wiedzy, informacji i technikach komunikacyjnych, stąd często nazywane jest społeczeństwem informacyjnym, a nawet społeczeństwem sieci. Uznaje się, że procesy globalizacyjne, w których to grupy społeczne uzyskują odpowiednią wiedzę i umiejętnie wykorzystują informacje, przynoszą z sobą rozwój. Ważną cechą procesów jest występowanie zjawisk przeciwnych, takich jak glokalizacja. Globalności towarzyszą więc naciski na znaczenie lokalności i apele o pielęgnowanie tożsamości, co według badaczy jest zjawiskiem naturalnym $\mathrm{i}$ komplementarnym do procesów globalizacyjnych [Karwińska, 2008].

Ważnym elementem w zarządzaniu rozwojem miast jest marketing. Stygmatyzowane ośrodki i dzielnice zniechęcają inwestorów oraz potencjalnych mieszkańców do lokowania swojego kapitału, tym samym ograniczając szanse na rozwój. Budowanie przewagi konkurencyjnej powinno się rozpocząć od rozważań na temat sposobów kształtowania pozytywnego obrazu miasta lub całych dzielnic. Odkrywanie potencjału oraz mocnych stron danych lokalizacji często zajmuje wiele lat [Markowski, 1999].

Podnosząc wartość rynkową i wizerunkową dzielnic, wielkie miasta zmagają się ze zjawiskiem odpływu mniej zamożnej ludności do biedniejszych obszarów, o niskim poziomie bezpieczeństwa i atrakcyjności osiedlania się. Takie zjawisko opisywane przez badaczy [Węcławowicz, 2007; Gądecki, 2012], noszące miano gentryfikacji, jest niebezpieczne i w dzielnicach zyskujących wyższy status może prowadzić do tak zwanej gettoizacji, czyli tworzenia się współczesnych gett biedy na obrzeżach wielkich miast. Wyzwanie, jakie niesie przedstawiony problem, powinno być poddane szerokiej analizie podczas wdrażania założeń rewitalizacji. Należy pamiętać, iż nędza w polskich miastach często dotyczy grup, które nie 
potrafiły odpowiednio wykorzystać dobrodziejstw okresu transformacji i zostały tym samym odsunięte od dobrobytu, jaki dla niektórych przyniosła [Węcławowicz, 2007]. W Nowej Hucie skala tego zjawiska jest wysoka, biorąc pod uwagę, iż według badań z końca lat $90.10 \%$ przebadanych mieszkańców żyło o ubóstwie [Stenning, 2008].

Reasumując, miasta wybierają wiele kierunków rozwoju, budując przewagę konkurencyjną opartą na marketingu, odpowiedniej strategii oraz zarządzaniu rozwojem intelektualnym lokalnej społeczności. Odpowiednim elementem polityki rozwoju miasta jest właściwe rozpoznanie potencjału oraz budowanie konkurencyjności obszarów. Identyfikacja potrzeb lokalnych społeczności jest jednym z wyzwań dla władz lokalnych budujących strategie rozwoju i programy operacyjne.

\section{Wyzwania dla zarządzania rozwojem Nowej Huty}

Rosnące bezrobocie oraz niepewna przyszłość Kombinatu pozbawiły mieszkańców Nowej Huty poczucia stabilności i bezpieczeństwa. Odwiedzając dzielnicę na początku lat 90., Allison Stenning, prowadząca badania społeczne, zaobserwowała, iż sytuacja związana z diametralną zmianą życia, do jakiego przywykła społeczność tego obszaru, wprowadziła atmosferę zawieszenia i oczekiwania, nie tylko wśród starszych, ale również, co najbardziej niepokojące, wśród młodych mieszkańców dzielnicy, mocno odczuwających wpływ przeobrażeń systemu na życie ich rodziców czy dziadków [Stenning, 2008]. Nowa Huta - rozumiana jako tak zwana stara część - w okresie po upadku socjalistycznego reżimu liczyła ponad 50 tysięcy mieszkańców, a wraz z innymi, mentalnie i zwyczajowo pojmowanymi osiedlami należącymi do tego rejonu - ponad 200 tysięcy zameldowanych osób. Problem dotyczył więc w swojej skali czterech średniej wielkości miast Polski [Płaziak, 2014].

Studium uwarunkowań i kierunków zagospodarowania przestrzennego Krakowa z 2003 roku, ustanowienie użytku ekologicznego - Łąk Nowohuckich, otworzenie, dzięki staraniom lokalnych środowisk, Muzeum Historycznego Miasta Krakowa - Oddziału Nowohuckiego [Bujak, Ryłko, 2008], lokalny plan rewitalizacji „starej” Nowej Huty czy projekt Nowa Huta Przyszłości to dokumenty i działania, jakie pojawiły się dopiero po 2000 roku. W Strategii Rozwoju Miasta Krakowa Nowej Huty nie uwzględniono w obszarach „Aktywność Gospodarcza” i „Aktywność Naukowo-Technologiczna”. Pojawia się jedynie w sekcji „Kultura i Dziedzictwo Narodowe" (Priorytetowe Projekty Inwestycyjne) pod hasłem Rewitalizacji zespołu urbanistycznego Nowej Huty - choć rewitalizacja winna być pojęciem pojmowanym szerzej - nie tylko jako poprawa wyglądu budynków, ale też jakości życia mieszkańców, przyczyniającej się do pobudzenia przedsiębiorczości i rozwoju społeczności [Skalny; Białecka, 2015]. Nowa Huta pojawia się, także w obszarze „Turystyka, sport, rekreacja” pod hasłem „Zagospodarowanie Łąk Nowohuckich”, a także w Strategii Rozwoju Turystyki w kategorii „Produkt Turystyczny Krakowa” - turystyka religijna, gdzie jako jeden z obiektów wartych 
polecenia turystom widnieje kościół o znaczeniu historycznym dla Nowej Huty - Arka Pana.

Niemniej jednak w Nowej Hucie pojawiło się wiele oddolnych inicjatyw, które w dużej mierze przyczyniły się do zdynamizowania procesów odradzania się dzielnicy. Warto w tym miejscu wspomnieć o zasługach Forum na rzecz Nowej Huty, działalności kulturalno-oświatowej Ośrodka Kultury C.K. Norwida czy Teatru Ludowego oraz związanej z nim Fundacji Ukryte Skrzydła. W 2005 roku do Nowej Huty przeniósł swoją siedzibę Teatr Łaźnia Nowa, co spowodowało przemieszczanie się gości spektakli w rejon Nowej Huty i ożywienie dzielnicy pod względem wydarzeń kulturalnych. Wiele organizacji przez lata starało się przywrócić pamięć o Nowej Hucie oraz wzbudzić w jej mieszkańcach zryw przedsiębiorczy i ekologiczny wraz z nowymi pomysłami dotyczącymi tego, jak sprawić, by Nowa Huta weszła na nowo w fazę rozwoju. W 2011 roku powstała przy Urzędzie Miasta Komisja Dialogu Obywatelskiego do spraw Rewitalizacji Nowej Huty, w skład której wchodzili przedstawiciele kilku organizacji pozarządowych. Jednak od 2014 roku jej aktywność wydaje się silnie ograniczona, zwłaszcza że od tego czasu nie zostały opublikowane roczne sprawozdania na temat jej działalności. Należy zauważyć również krytyczny głos mieszkańców Nowej Huty w stosunku do władz Krakowa wyrażany przez stowarzyszenie Magistrat Nowohucki - organizację pozarządową, która po kilku latach rozmów i rozważań nad przyszłością Nowej Huty została oficjalnie powołana do życia w 2014 roku. Główną ideą przyświecającą działalności tej organizacji jest odłączenie Nowej Huty od Krakowa. Postulaty Magistratu odwołują się do historii Nowej Huty, która w założeniu miała działać jako osobne miasto, dysponując niezbędnym do samodzielnego funkcjonowania zapleczem, zarówno usługowym, jak i instytucjonalnym czy infrastrukturalnym.

Niewątpliwie wizerunek miasta czy osiedla wpływa na inwestycje czy preferencje osiedleńcze. Wizerunek budowany jest przez lata, ale nie jest kategorią stałą i zmienia się w zależności od informacji, jakie odbieramy na temat danego obiektu. Istotną rolę zaś w tworzeniu takiego obrazu odgrywają mass media. Poprzez przekazy słowne i pisemne nasze wyobrażenia nabierają kształtów i przekładają się na związane pozytywne lub negatywne odczucia wobec określonego przedmiotu rozważań [Gądecki, 2013]. Jednym z wyzwań, jakie stawia Nowa Huta obecnie, jest budowa pozytywnego wizerunku oraz uczynienie dzielnicy bardziej atrakcyjną dla potencjalnych nowych mieszkańców czy lokacji istotnych z punktu widzenia miasta, instytucji publicznych. Wizerunek Nowej Huty przez lata był przedstawiany przez pryzmat rozbojów i kradzieży, a „czarne legendy” o dzielnicy wpływały na wskaźnik popularności i prestiżu, ujawniający się na przykład w cenach mieszkań, które były znacząco niższe od cen nieruchomości w innych obszarach Krakowa [Golonka-Czajkowska, 2013]. Mimo notowanej w ostatnich latach stosunkowo niskiej liczby przestępstw i wykroczeń (w porównaniu do innych części miasta, zgodnie danymi przedstawionymi na kryminalnej mapie Krakowa), dzielnica nadal przez wiele osób - zarówno mieszkających w Krakowie, jak i odwiedzających miasto - jest uznawana za miejsce nieatrakcyjne i niebezpieczne. 
Wspomniane inicjatywy oddolne i podejmowanie współpracy z władzami miasta są kolejnym krokiem do poprawy wizerunku Nowej Huty.

Zabudowa oraz charakter i dzieje dzielnicy są niezwykle interesującym elementem powojennej historii Krakowa, nie sposób więc pominąć tych aspektów podczas prezentacji Krakowa w kontekście turystycznym. Nowa Huta jest bogatym laboratorium zarówno dla socjologów, jak i urbanistów, idealnym miejscem badań dla wielu osób z Polski, z Europy czy ze świata. Ze względu na swoją historię i unikatową siatkę urbanistyczną Nowa Huta, za sprawą działaczy społecznych oraz Urzędu Miasta Krakowa, ubiega się o wpisanie swojego centrum na listę pomników historii UNESCO. Jest to kolejny bodziec do spojrzenia na Nową Hutę z perspektywy korzyści turystycznych i rozwoju zaplecza usługowego dzielnicy w postaci muzeów, galerii, kawiarni i restauracji zwłaszcza w rejonie placu Centralnego i Alei Róż.

Raport dotyczący realizacji Lokalnego Planu Rewitalizacji „starej” Nowej Huty opisuje wdrożone działania zrealizowane podczas pierwszej fazy projektu. Dotyczą one odnowy i modernizacji budynków, w mniejszym stopniu analizując wpływ przemian przestrzeni publicznej na społeczność lokalną. Nowa Huta wymaga bowiem odpowiedniej modernizacji zarówno ze względu na postępującą przez wiele lat degradację tkanki miejskiej [Płaziak, 2014], jak i działania związane z dbałością o poziom życia mieszkańców. Wspomniane zjawisko gentryfikacji jest często wiązane przez badaczy z rewitalizacją bądź „odnową miejską”, a nawet traktowane jako jej wynik, jednak w odniesieniu do miasta postkomunistycznego, jakim jest Nowa Huta, uznaje się gentryfikację za zjawisko marginalne, ponieważ własność mieszkań jest rozproszona bądź pozostaje w rękach spółdzielni mieszkaniowych, stąd przenoszenie do centrum Nowej Huty inwestycji bądź ważnych wydarzeń kulturalnych nie powinno w przyszłości prowadzić do negatywnych zmian w strukturze społecznej dzielnicy. Dlatego też studia nad gentryfikacją powinny stanowić jeden z obszarów analizy w zarządzaniu rozwojem Nowej Huty [Gądecki, 2013]. Wykorzystanie unikatowej pod względem architektonicznym zabudowy jako atutu dzielnicy, z szerokimi alejami oraz przejrzystym i zorganizowanym układem połączeń drogowych, powinno w przyszłości przekładać się na koncentrację wydarzeń kulturalnych w tym obszarze, napędzających lokalną przedsiębiorczość oraz stanowić poprawę warunków życia lokalnej społeczności.

\section{Podsumowanie}

Nowa Huta powinna być traktowana jako jeden z istotnych obszarów strategii rozwoju Krakowa. Odpowiednie rozpoznanie potencjału dzielnicy oraz przeprowadzenie zmian $\mathrm{w}$ przestrzeni miejskiej i wizerunku będzie miało ważne znaczenie podczas dalszego rozwoju miasta. Dzięki opracowanej analizie społecznej oraz docenieniu wartości turystycznej i kulturalnej Nowa Huta jest w stanie osiągnąc odpowiedni poziom przemian i umocnić pozycję dzielnicy przyjaznej zarówno mieszkańcom, turystom, małym i średnim przedsiębiorstwom, 
jak i znaczącym inwestorom. Z rozwojem wiążę się jednak ryzyko gentryfikacji i pogłębienia wykluczenia określonych grup społecznych, stąd też aktywizacja społeczności dzielnicy powinna być jednym z głównych obszarów zainteresowań władz miasta. Są to jednak działania długookresowe, wymagające współpracy między organizacjami pozarządowymi, instytucjami publicznymi i mieszkańcami.

\section{Bibliografia}

Bujak K., Ryłko E. (2008), Czy Nowa Huta to nowa szansa? Opinie i postawy grup beneficjentów programu Partnerstwa Inicjatyw Nowohuckich: „Nowa Huta - Nowa Szansa” [w:] Kurkiewicz A. (red.), Zrozumieć Nowa Hutę, Wydawnictwo Uniwersytetu Jagiellońskiego, Kraków.

Gądecki J. (2012), Gentryfikacja starej części Nowej Huty, Wydawnictwo IFiS PAN, Warszawa.

Gądecki J. (2013), Odkrywając miasto idealne? Marginalna gentryfikacja starej części dzielnicy Nowa Huta, „Studia Regionalne i Lokalne”, 4(54).

Golonka-Czajkowska M. (2013), Nowe miasto nowych ludzi: Mitologie nowohuckie, Wydawnictwo Uniwersytetu Jagiellońskiego, Kraków.

Jeleński T. (2010), Studium przypadku 10.P1 [w:] J. Kronenberg, T. Bergier (red.), Wyzwania zrównoważonego rozwoju w Polsce, Centrum Rozwiązań Systemowych, Wrocław.

Karwińska A. (red.) (2008), Odkrywanie socjologii, Wydawnictwo Naukowe PWN, Warszawa.

Markowski T. (1999), Zarządzanie rozwojem miast, Wydawnictwo Naukowe PWN, Warszawa.

Płaziak M. (2014), Przemiany funkcji handlowo-usługowych w mieście postsocjalistycznym na przykładzie Nowej Huty [w:] E. Kaczmarska, P. Raźniak (red.), Społeczno -ekonomiczne i przestrzenne przemiany struktur regionalnych, t. 1, Oficyna Wydawnicza AFM, Kraków.

Pęski W. (1999), Zarządzanie zrównoważonym rozwojem miast, Wydawnictwo Arkady, Warszawa.

Siemieńska R. (1969), Nowe życie w nowym mieście, Wiedza Powszechna, Warszawa.

Skalny A., Białecka B. (2015), Kierunki przekształceń terenów poprzemysłowych, „Zeszyty Naukowe. Organizacja i Zarządzanie", Politechnika Śląska, 82.

Stenning A. (2008), Why Nowa Huta? [w:] A. Kurkiewicz (red.), Zrozumieć Nowa Hutę, Wydawnictwo Uniwersytetu Jagiellońskiego, Kraków.

Węcławowicz G. (2007), Geografia społeczna miast, Wydawnictwo Naukowe PWN, Warszawa. 


\section{Dokumenty elektroniczne}

Strategia Rozwoju Turystyki w Krakowie na lata 2014-2020 (2014), Urząd Miasta Krakowa Wydział Promocji i Turystyki, Kraków.

Strategia Rozwoju Krakowa (2005), Urząd Miasta Krakowa - Wydział Rozwoju Miasta, Kraków.

Uchwała Nr Liii/674/08 Rady Miasta Krakowa z dnia 8 października 2008 r. w sprawie przyjęcia Lokalnego Programu Rewitalizacji ,starej” Nowej Huty (2008), Urząd Miasta Krakowa, Kraków.

Uchwała Nr Lxxv/742/05 Rady Miasta Krakowa z dnia 13 kwietnia 2005 r. w sprawie przyjęcia Strategii Rozwoju Miasta Krakowa (2005), Urząd Miasta Krakowa, Kraków.

Uchwała Nr Xlv/431/04 Rady Miasta Krakowa z dnia 28 kwietnia 2004 r. w sprawie działań zmierzajacych do uznania Nowej Huty za pomnik historii $i$ wpisania jej na listę Światowego Dziedzictwa Kultury UNESCO (2004), Urząd Miasta Krakowa, Kraków

\section{Strony internetowe}

Magistrat Nowohucki, www.magistratnowohucki.pl [dostęp: 20.12.2016].

Ośrodek Kultury C.K. Norwida, http://www.okn.edu.pl [dostęp: 18.12.2016 ].

Teatr Ludowy, www.ludowy.pl [dostęp: 20.12.2016 ].

Fundacja Ukryte Skrzydła, www.ukryteskrzydla.pl [dostęp: 15.12.2016].

Teatr Łaźnia Nowa, www.laznianowa.pl [dostęp: 20.12.2016 ].

Mapa Kryminalna, www.mapakryminalna.pl [dostęp: 20.12.2016 ]. 